\title{
An Automated Early Alert System for Natural Disaster Risk Reduction: A Review
}

\author{
Hawkar Jabbar H. Ali
}

Technical Informatics College of Akre, Duhok Polytechnic University, Duhok, Kurdistan Region, Iraq, hawkarrrr87@gmail.com

\section{Karwan Jacksi}

Department of Computer Science, University of Zakho, Zakho, Kurdistan Region, Iraq Karwan.Jacksi@uoz.edu.krd

\section{ARTICLE INFO}

\section{Article History:}

Received: Jan 20.2021

Accepted: 16/2/2021

Published: Winter 2021

\section{Keywords:}

Disaster, Risk

Reduction, GIS

application, Weather

Prediction.

Doi:

10.25212/Ifu.qzj.6.1.34

\section{ABSTRACT}

According to the research published in the last decades, many peoples died due to natural disasters. So, some researchers tried to find a method and solution to reduce these disasters and risks. Lamentably, there is not any value system for a warning from certain dangerous disasters in the country. This suggestion is constructive to diagnose this kind of problem; every country follows different tactics. Based on the various sources of natural weather monitoring systems in the heterogeneous country regions, this review found no solution to warn the community in real-time. This examination is to find the weakness of the current situation as the growth of technology nowadays. Today mobile application's new technology helps an early alert system for natural disaster risk reduction (DRR) that authorities employed in several ways to reduce the natural disaster risks. 


\section{Introduction}

In the world, as per the record of Emergency Events Database, natural hazards have the cost of three trillion dollars of economic destruction and 1.3 million casualties with more than 4.4 billion people injured between 1998 and 2017, according to the research of C. Center for Research on Epidemiology of Disasters, (2018) Economic losses [12]. This information is really helpful when tourists travel to any place, maybe the traveler does not have any erudition about the disasters. Besides, most of the people in the country also do not have any information about the weather of their cities, and some of the other factors correlated with natural disasters.

Notwithstanding the development of many various technology-aided systems to understand and mitigate the effects of natural risks, effective disaster prediction and management continue to remain a global issue. In 2019, as per Ujjwal et al., natural disasters caused a significant loss of human life every year throughout the world [2]. According to Takako Izumi, the social sciences and social media play a prominent role in developing new thinking on risks, disasters, vulnerabilities, and poverty and the human roles in Disaster Risk Reduction (DRR) [6].

In this literature, many different models and applications design using to warn people from natural disasters. Takako Izumi enlightens these models and applications such as do a survey, using Google Map (In 2016, Sarah et al. [15]), Information Communication Technology (In 2019, Ujjwal et al. [2]), online social media (In 2018, Rossi et al. [10]), Web-GIS tool (Alfredo Mahar Francisco A. Lagmay [14]), Facebook and WhatsApp (In 2019, Bhuvana and Aram [5]), and Twitter (Akemi Takeoka Chatfield) and soon. Fortunately, DRR is a systematic approach to identifying, assessing, and disaster risk-reducing, and it helps to minimize the vulnerability of a society or community (Onstada et al. 2012 [18]), so it can solve some problems by creating a mobile application and a website to get the weather information through an online network from anywhere and anytime. Due to these online resources, it is an immeasurable try to find a relevant solution for the DRR problems faced by tourists and civilization for solving the problem. 
For this analysis, based on the sources of natural weather monitoring in the Kurdistan region, there will be tried to create an Application for mobiles to have an early alert system for natural disaster risk reduction that scholars used in different ways for reducing the natural disaster risks, and sending a notification and warning from the sources to the user for any natural disasters. In this research study, some of the papers and research are very similar and relevant to my work to determine the problems and methods in solving the issues. Then pick the best solution to detect and reduce natural risks in the country.

\section{Literature review}

In 2016, Sarah et al. [15] proposed an android application for managing a disaster based on the google map. In the presented system, users could register several persons as a friend and family member to send them a notification and asking them help. The mechanism of the system was to send the shortest path of the shelter or save zone of the disaster position captured by GPS. Moreover, the authors designed this system in a way that even blind people could use and depend on it through voice calls when needed. By the designed system, people got appropriate help and they could avoid disaster by going to save place.

In 2019, El-Kholei [4] presented a study based on the UNISDR reports that have been achieved in the different Arab cities. The research examined the Arab cities preparedness level for natural risks. Moreover, the study aimed to investigate the commonalities among the Arab cities based on mixed research method and then examined determinants of preparedness. The results illustrated that the Arab cities are not prepared and there is a desired requirement for developing early warning systems.

In 2018, Bahraminejad et al. [9] proposed an early warning system to overcome the shortages in protected-area management in the eastern Iran. The method based on the pressure state response approach and ecological security index. The proposed system based on the ecological security index status in the study area, statistical 
analysis, and expert opinions, three indicators "precipitation, vegetation covering status, and soil brightness" were chosen as the main and final indicators. The results indicated that the some region of the area under study were in warning status and need a decision. The authors concluded that there is a need for further studies in the less developed countries and the study area could be divided into more categories.

In 2019, Ujjwal et al. [2] proposed a cloud computing framework of services to offer the functionality of hazard models. Besides, to overcome cloud issues such as communication and electricity infrastructure breakdown during the disaster, they involved cloud technology with other technologies such as Internet of Things (IOT) network, fog, and edge computing. As a result, important services related to the disaster were offered and these technologies could act as data transitional. The researchers concluded that natural disaster management could be enhanced by deploying a combined system of integrated Geospatial intelligence systems, ingesting real-time Remote Sensing, and spatial data feed with advanced visualization technologies deployed over the web.

In 2012, Intrieri et al. [19] described an early warning system for the rockslide of two roads in Torgiovannetto Italy. The proposed system was consisted of geological knowledge, the risk scenarios, and the kinematic characterization of the landslide, the choice and installation of the monitoring system, the setting of appropriate alarm levels and the definition of plans of civil protection. Moreover, the presented system was comprised of 13 wire extensometers, 1 thermometer, 1 rain gauge and 3 cameras. When the change of the landslide occurred, the system hinted an imminent failure and hence an alarm was issued, then the road been closed by the system.

In 2018, Rossi et al. [10] proposed an early flood detection set of services based on the weather forecasting related to event detection and social media information extraction. They depended on the data that have been generated on Twitter for introduced floods in the north of Italy. Moreover, the authors used a fast text tool that has been developed by the Al research group of Facebook to extract important 
information through Twitter text during emergencies. Further, in the presented method the key phrase extraction as a qualitative confirmation tool has been used for weather forecaster. The results illustrated that the past data generated from an emergency event could be used to train machine-learning methods well on new data.

In 2019, Bhuvana and Aram [5] presented a quantitative study on social media especially on Facebook and WhatsApp were been utilized as disaster management tools in the Chennai floods of 2015, in south India. The authors depended on several factors such as information, real-time operational information, emotional appeal, situational updates, and trustworthiness as the satisfaction level of using both platforms among the resident of the Chennai city. They indicated that Facebook and WhatsApp been used more than traditional communication tools such as radio and TV during the Chennai flood. Moreover, the study analyzed that the information put in both social media platforms helped to determine which area of the city need more resources, and helped authority in decision making in that real disaster.

In 2015, Mandale and Jadhawar [17] used two data mining techniques for weather forecasting. They depend on the Artificial Neural Network (ANN) and C5 Decision tree algorithms to perform weather variable classification. In more detail, the $\mathrm{C} 5$ algorithm has classified weather parameters such as maximum temperature, minimum temperature, rainfall, evaporation, and wind speed in terms of the month and years. Moreover, the study indicated that the ANN could predict the weather condition of the future by giving enough data to the algorithm and depending on the detecting relationship of the weather parameter.

In 2012, Rahman et al. [20] proposed an early warning disaster and evacuation location-based system. The presented system was implemented for both blind and normal based on the Open Street Map for android mobile. Moreover, the system consisted of the disaster management server and the android application. Data of the weather such as tsunami, flood, and cyclone was stored and updated on the disaster management server. Users registered their mobile devices on the android cloud to 
get notification and the user location data were updated on the disaster management server through GPS. The ray-casting algorithm used to determine the affected area that the disaster was probable. Further, when the probable zone detected by the application then the disaster warning and the evocation guideline were disseminated by the application. The results illustrated that the proposed system was effective.

In 2019, Qiao et al. [3] developed a geomagnetic inductive current (GIC) early warning and monitoring system. They used a cloud server to store data, realize monitoring, early warning, and prediction. Moreover, in the presented system, the weather space data for forecast were combined to perform an early warning system and to monitor the transformer for neutral GIC in real-time. The designed system aimed to achieve four functions, which were real-time data, data receiving of geomagnetic, predictive data, and predictive warning. The experiment showed the activity of the system in interacting with the server and the user side received data in real-time.

In 2017, Heryana et al. [13] developed an android based application as an early warning system for earthquake and landslide by using the Agile method. The designed application recorded data by the mobile sensor and for analysis, the recorded data sent to a server in order to distinguish between normal and abnormal vibrations. The researchers only described the design level of the proposed system in this research. In general, the proposed system consisted of two parts: the cloud part that involved of a web server, Rest API, GIS and machine learning processor; the smartphone part, which included of accelerometer and GPS sensors.

In 2015, Rapant et al. [16] proposed an early warning system for the heavy rain indication in risk areas in the Czech Republic. The proposed system based on the weather radar for data processing and heavy rainfall detection in the affected area. The main objective of the system was to detect heavy rain in the risk zone and to give an early notification to the risk area. The authors thoughts that their system could be very useful in area that expose to heavy rain in order to prevent the risk produced of that rain and to reduce damages. 
In 2018, Yendri and Septiawan [11] built an early warning system based on the Raspberry $\mathrm{Pi}$ as a control center. The proposed system was designed for a dam in Padang city to observe the water level and weather of the dam. DHT11 sensor and cup propeller were used to read the weather environment, temperature, humidity, and wind speed. Moreover, the fuzzy logic has been utilized to process weather data and to get weather categories such as sunny, cloudy, light rain, and heavy rain. Further, the ultrasonic sensor was utilized to read the dam's water level and weather category and to reprocess them to safe, standby, warning, and dangerous information. The experiments illustrated the success rate of the proposed flash flood early running system was $70 \%$.

In 2019, Bai et al. [7] aimed to automatically identify the rock falling on the road, as an early warning and disaster identification system. The system was a combination of artificial intelligence and manual control and based on the geological hazards remote monitoring system for Beijing high road. In the proposed system, videos captured by different cameras were stored on a server as a basic database. Then from the archived data, a piece of valuable information extracted by the using clustering technology. Moreover, the genetic algorithm was used as a preprocessing step for discovering knowledge from the massive obtained data and to identify and detect rock falling. Further, the deep convolutional neural network (DCNN) used to improve the system and to solve the video image recognition problem. In addition, several visualization technologies used to display the analyzing results and release the early warning system.

In 2020, Athirah et al. [1] developed an alert warning system for flood based on solar energy as a power supply and short message service (SMS) notification. The presented system notified the residents about the water level condition by sending them a message via using GSM. Therefore, the authors used three LEDs (green, yellow, and red) to indicate the water level heights and notify the community about it. In general, the proposed system consisted of the Arduino Uno, GSM module, water level sensor, mobile phone, LEDs, and solar panel. The solar panel was used to 
overcome the power problem, the water level sensor was used to detect the water level height and the Arduino Uno was used as the microcontroller of the system. The microcontroller has received information about water level height. Moreover, the received information processed by the microcontroller and then sent by the Arduino device to the GSM shield. Further, the GSM shield has been used to send the information about the water level and flood warning alert to the registered phone number of the residents.

In 2018, Gian et al. [8] designed a flexible system for monitoring and early warning of rainfall-induced landslide based on wireless sensor networks. The proposed system was done through the combination of the start and tree topologies. The start topology was used for the sensor nodes around the gateway node, but the tree topology was used for other nodes. Moreover, the proposed system was consisted of six sensor nodes and placed in different locations. Further, the used sensors nodes were capable of sending and receiving data to the gateway node without depending on each other. The experiment showed that the presented system improved the operation reliability and less energy consumption compared with the systems who depended only on the start topology or tree topology.

\section{Discussion}

In the previously mentioned literature reviews, that is visible diverse researches have been published and focused on the Natural Disaster Risk reduction (NDRR) due to its importance. This study showed that disaster risk reduction monitoring, having a warning system, determination, and focusing on the motivating to use these applications that related to the disasters and analyzing the user application that they are different for a country to another.

In the following table, research [1] [2] [4] [5] [10] [13] [15] [20] use technologies a mobile phone, GPS, Google MAP, data analysis software for detecting Flood, Tsunami, wind storm, and earthquake to alarm people avoid disaster and reach a safe place utilizing this system. Here, the study [19] practices wire extensometers, 


\section{QALAAI ZANISTSCIENTIFIC JOURNAL}

A Scientific Quarterly Refereed Journal Issued by Lebanese French University - Erbil, Kurdistan, Iraq

Vol. (6), No (1), Winter 2021

ISSN 2518-6566 (Online) - ISSN 2518-6558 (Print)

thermometers, rain gauges, and cameras to recognize rockslides to scare the road closed while the system issues a warning. The investigation [17] [3] [16] [11] applies GPS, prediction (ANN and C5 Decision tree algorithms) Raspberry Pi, DHT11 sensor, and fuzzy logic to identify wind storms and floods adopting the ANN algorithm to predict future weather statuses in real-time. It is least not the last researches [7] [8] applies Clustering technology, Wireless sensor networks, genetic algorithm, and DCNN to identify rockslides, Flood, and landslides to terrify disaster identification operations reliability, and management improved.

\begin{tabular}{|c|c|c|c|c|}
\hline Author(s) & Year & Used Technology & Disaster Type & Results \\
\hline [1] & 2020 & $\begin{array}{l}\text { Mobile phone and } \\
\text { GPS }\end{array}$ & Flood & $\begin{array}{l}\text { The residents got information } \\
\text { and warning about water level. }\end{array}$ \\
\hline [2] & 2019 & $\begin{array}{l}\text { Mobile phone and } \\
\text { social media }\end{array}$ & $\begin{array}{l}\text { Flood and } \\
\text { wind storm }\end{array}$ & $\begin{array}{l}\text { Natural disaster management } \\
\text { enhances by deploying a } \\
\text { combined intelligence system, } \\
\text { remote sensing, and advanced } \\
\text { web technologies. }\end{array}$ \\
\hline [3] & 2019 & GPS and prediction & Flood & $\begin{array}{l}\text { The system was efficient and } \\
\text { users received data in real time. }\end{array}$ \\
\hline [4] & 2019 & $\begin{array}{l}\text { Data analysis } \\
\text { software }\end{array}$ & $\begin{array}{l}\text { Flood, } \\
\text { Earthquake }\end{array}$ & $\begin{array}{l}\text { There is a desired requirement } \\
\text { for developing early warning } \\
\text { systems because the Arab cities } \\
\text { are not prepared well for the } \\
\text { disasters. }\end{array}$ \\
\hline [5] & 2019 & $\begin{array}{l}\text { Mobile phone and } \\
\text { social media }\end{array}$ & Flood & $\begin{array}{c}\text { Social media information could } \\
\text { help disaster management. }\end{array}$ \\
\hline [7] & 2019 & $\begin{array}{c}\text { Clustering } \\
\text { technology, } \\
\text { genetic algorithm } \\
\text { and } \\
\text { DCNN }\end{array}$ & Rockslide & $\begin{array}{l}\text { The disaster identification and } \\
\text { management improved. }\end{array}$ \\
\hline [8] & 2018 & $\begin{array}{c}\text { Wireless sensor } \\
\text { networks }\end{array}$ & $\begin{array}{l}\text { Flood and } \\
\text { landslide }\end{array}$ & $\begin{array}{l}\text { The operation reliability } \\
\text { improved. }\end{array}$ \\
\hline [9] & 2018 & $\begin{array}{l}\text { The ecological } \\
\text { security index status } \\
\text { in the study area, } \\
\text { statistical analysis, } \\
\text { and expert opinions }\end{array}$ & - & $\begin{array}{l}\text { There is a need for further } \\
\text { studies in the less developed } \\
\text { countries. }\end{array}$ \\
\hline
\end{tabular}




\section{QALAAI ZANISTSCIENTIFIC JOURNAL}

A Scientific Quarterly Refereed Journal Issued by Lebanese French University - Erbil, Kurdistan, Iraq

Vol. (6), No (1), Winter 2021

ISSN 2518-6566 (Online) - ISSN 2518-6558 (Print)

\begin{tabular}{|c|c|c|c|c|}
\hline [10] & 2018 & Social Media & Flood & $\begin{array}{l}\text { The past emergency event data } \\
\text { used to train machine-learning } \\
\text { methods well. }\end{array}$ \\
\hline [11] & 2018 & $\begin{array}{l}\text { Raspberry } \mathrm{Pi} \\
\text { DHT11 sensor and } \\
\text { fuzzy logic }\end{array}$ & Flood & $\begin{array}{c}\text { The success rate of the } \\
\text { proposed early running system } \\
\text { was } 70 \% \text {. }\end{array}$ \\
\hline [13] & 2017 & $\begin{array}{l}\text { Mobile phone, GIS } \\
\text { and GPS }\end{array}$ & Earthquake & $\begin{array}{l}\text { The authors only described the } \\
\text { design of the system. }\end{array}$ \\
\hline [15] & 2016 & $\begin{array}{l}\text { Mobile phone, GPS, } \\
\text { Google MAP }\end{array}$ & $\begin{array}{l}\text { Flood, } \\
\text { Tsunami, } \\
\text { Tourists }\end{array}$ & $\begin{array}{l}\text { People could avoid disaster and } \\
\text { reach to save place by using this } \\
\text { system. }\end{array}$ \\
\hline [16] & 2015 & Prediction & Flood & $\begin{array}{c}\text { The system was helpful to } \\
\text { prevent risk and reduce the } \\
\text { damages. }\end{array}$ \\
\hline [17] & 2015 & $\begin{array}{c}\text { Prediction (ANN and } \\
\text { C5 Decision tree } \\
\text { algorithms) }\end{array}$ & Wind storm & $\begin{array}{l}\text { The ANN algorithm could } \\
\text { predict the future weather } \\
\text { condition. }\end{array}$ \\
\hline [19] & 2012 & $\begin{array}{c}\text { Wire } \\
\text { extensometers, } \\
\text { thermometer, rain } \\
\text { gauge and cameras }\end{array}$ & Rockslide & $\begin{array}{l}\text { The road has been closed when } \\
\text { an alarm issued by the system. }\end{array}$ \\
\hline [20] & 2012 & $\begin{array}{l}\text { Google map, mobile } \\
\text { phone and GPS }\end{array}$ & $\begin{array}{l}\text { Flood and } \\
\text { wind storm }\end{array}$ & $\begin{array}{l}\text { Experiments showed the } \\
\text { effectiveness of the application. }\end{array}$ \\
\hline
\end{tabular}

\section{Conclusion}

The findings in this reviewed research explored disaster risk reduction as one of the vital issues to be studied, discussed, and protect peoples from these disasters. Mobile phones, applications, the internet, and other technologies have the primary role in warning peoples of natural disasters and risks. Therefore, notably in countries with consecutive natural disasters (floods, earthquakes, snowdrift, and volcanoes), companies and researchers moved towards adopting natural disasters, reducing them, and warning about protecting these debacles' peoples. According to the countries' different strategies, the researchers performed another method for natural reduction disasters. Based on these papers that it reviewed, there existed no application for warning people in real-time. 
It concludes with designing and implementing a mobile application for mobile devices to cognizant society or community before any natural disaster arises. Next, link this application with weather detecting centers in the country regions. Following that, weather centers send a message for connected mobile nodes to have the application. Moreover, they were warning from the location of the disaster with the help of GIS software.

Future work will suggest increasing the quality and number of centers regarding weather prediction in real-time.

\section{References:}

[1] N. A. Athirah, N. H. Radzi, M. N. Abdullah, S. A. Jumaat, and N. Z. Mohamad, "Solarpowered flood early warning system with short message service (SMS) notifications," Indonesian Journal of Electrical Engineering and Computer Science, vol. 18, no. 3, pp. 1156-1162, 2020.

[2] K. C. Ujjwal, S. Garg, J. Hilton, J. Aryal, and N. Forbes-Smith, "Cloud Computing in natural hazard modeling systems: Current research trends and future directions," International Journal of Disaster Risk Reduction, vol. 38, p. 101188, 2019.

[3] J. Qiao, Q. Liu, and Y. Zhang, "Design of geomagnetic induction current monitoring and early warning system based on cloud server," in 2019 14th IEEE Conference on Industrial Electronics and Applications (ICIEA), 2019, pp. 1552-1556.

[4] A. O. El-Kholei, "Are Arab cities prepared to face disaster risks? Challenges and opportunities," Alexandria Engineering Journal, vol. 58, no. 2, pp. 479-486, 2019.

[5] N. Bhuvana and I. A. Aram, "Facebook and Whatsapp as disaster management tools during the Chennai (India) floods of 2015," International journal of disaster risk reduction, vol. 39, p. 101135, 2019.

[6] Takako Izumi, Rajib Shaw, Riyanti Djalante, Mikio Ishiwatari, Takeshi Komino, "Disaster risk reduction and innovations", Progress in Disaster Science, 2019.

[7] X. Bai, L. Sang, H. Kang, and Z. Liu, "Initial Thoughts and Application of Al in Geohazards Monitoring and Early Warning of Highroad in Beijing," in 2019 5th International Conference on Transportation Information and Safety (ICTIS), 2019, pp. 1358-1363. 
[8] Q. A. Gian, D. T. Tran, D. C. Nguyen, and T. D. Bui, "Flexible Configuration of Wireless Sensor Network for Monitoring of Rainfall-Induced Landslide," 2017.

[9] M. Bahraminejad, B. Rayegani, A. Jahani, and B. Nezami, "Proposing an earlywarning system for optimal management of protected areas (Case study: Darmiyan protected area, Eastern Iran)," Journal for Nature Conservation, vol. 46, pp. 79-88, 2018.

[10] C. Rossi et al., "Early detection and information extraction for weather-induced floods using social media streams," International journal of disaster risk reduction, vol. 30, pp. 145-157, 2018.

[11] D. Yendri and A. Septiawan, "Flash Flood Early Warning System Using Mini PC Case Study: Mount Nago Water Reservoir," in 2018 International Conference on Information Technology Systems and Innovation (ICITSI), 2018, pp. 448-453.

[12] C. Center for Research on Epidemiology of Disasters, (2018) Economic losses https://www.cred.be/sites/default/files/CRED/_Economic/_Losses/_10oct.pdf.

[13] A. Heryana, E. Nugraheni, B. Kusumo, A. F. Rojie, and B. Setiadi, "Applying agile methods in designing an earthquake and landslide early warning system application for Android," in 2017 International Conference on Computer, Control, Informatics and its Applications (IC3INA), 2017, pp. 80-84.

[14] Alfredo Mahar Francisco A. Lagmay, Bernard Alan Racoma, Ken Adrian Aracan,Jenalyn Alconis-Ayco, Ivan Lester Saddi, "Disseminating near-real-time hazards information and flood maps in the Philippines through Web-GIS", Journal of Environmental Sciences, vol. 59, pp. 13 - 23, 2017.

[15] S. Sarah, M. Dilip, and R. RahulAravindh, "Disaster alert and notification system via android mobile phone by using Google map," Int. Res. J. Eng. Technol, pp. 23950072, 2016.

[16] P. Rapant et al., "Early warning of flash floods based on the weather radar," in Proceedings of the 2015 16th International Carpathian Control Conference (ICCC), 2015, pp. 426-430.

[17] M. A. Mandale and B. A. Jadhawar, "Weather forecast prediction: a Data Mining application," Int J Eng Res Gen Sci, vol. 3, no. 2, 2015.

[18] Onstada PA, Danesb SM, Hardmanc AM, Olsonc PD, Marczakc MS, Heinsd RK, et al., "The road to recovery from a natural disaster: voices from the community". Community Development. 3(5):566-80, 2012. 


\section{QALAAI ZANISTSCIENTIFIC JOURNAL}

A Scientific Quarterly Refereed Journal Issued by Lebanese French University - Erbil, Kurdistan, Iraq

Vol. (6), No (1), Winter 2021

ISSN 2518-6566 (Online) - ISSN 2518-6558 (Print)

[19] E. Intrieri, G. Gigli, F. Mugnai, R. Fanti, and N. Casagli, "Design and implementation of a landslide early warning system," Engineering Geology, vol. 147, pp. 124-136, 2012.

[20] K. M. Rahman, T. Alam, and M. Chowdhury, "Location based early disaster warning and evacuation system on mobile phones using OpenStreetMap," in 2012 IEEE conference on open systems, 2012, pp. 1-6.

\section{سيستهمى ئاكَاداركردنهوهى خيّراى خوّكارانه بوّ كهمردنهوهى مهترسى كارهساتى سروشتى}

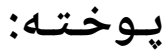

بهييّى ئهو تويّزينهوانهى له دهيان سالّى رابردوودا بِّاوكراوهتهوه ، جهندين كهس بههوّى كارهساتى سروشتيهوه كيانيان لهدهتداوه ـ بوّيه ههنديّك له تويّزهران ههولِيان داوه شيّواز و رِيّكه جارهيهك بدوّزنهوه بوّ كهمكردنهوهى ئهو كارهسات و مهترسيانه ـ به داخ و كهسهرييهوه هيج سيستهميّكى بهها بوّ ئاكاداركردنهوه له ههنديّك كارهساتى مهترسيدارى لهو ولّاتهدا نييه ـ ئهم يِيّشنياره دروستكهره بوّ

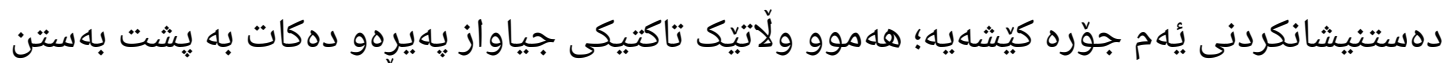
به سهرجاوه جوّراوجوّرهكانى سيستهمى جاوديّرى كه شوههواى سروشتى له ناوجه ناريّكه كانى ولّات ، ئهم يِيداجِوونهوهيه هيج جارهسهريّكى بوّ ئاكاداركردنهوهى كوّمهلّكه له كاتى رِاستهقينهدا

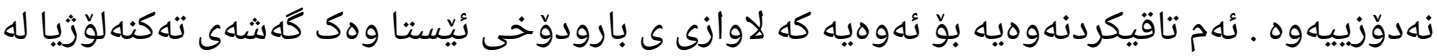

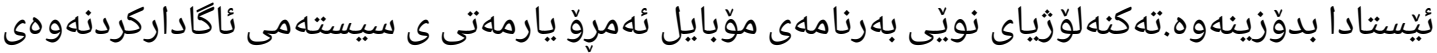
يِيشوهخت دهدات بوّ كهمكردنهوهى مهترسى كارهساتى سروشتى ( DRR ) كه دهسلَّاتداران به جهند ريّكايهك دامهزراون بوّ كهكردنهوهى مهترسى كارهساتى سروشتى . 


\section{QALAAI ZANISTSCIENTIFIC JOURNAL}

A Scientific Quarterly Refereed Journal Issued by Lebanese French University - Erbil, Kurdistan, Iraq

Vol. (6), No (1), Winter 2021

ISSN 2518-6566 (Online) - ISSN 2518-6558 (Print)

\section{نظام تنبيه ألي مبكر للحد من مخاطر الكوارث}

الملخص:

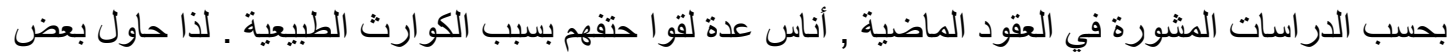
الباحثين أن يجدوا الطريقة و الحل لوضع حد لهذه الكوارث و المخاطر . و مع بالغ الأسف، لا يوجد أية نظام

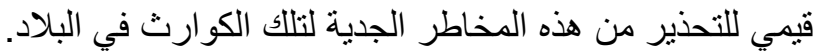

و هذا الاقتر اح تم بناءا على تشخيص هذا النوع من المشاكل، و كل بلد يتبنى تقنيات مختلفة بناءا على المصادر المختلفة لنظام مر اقبة الطقوس الطبيعية الغير متجاسة فيمناطق البلاد، و هذه المر اجع لم تف في ايجاد حل لتوعية المجتمع في الوقت الحاضر.

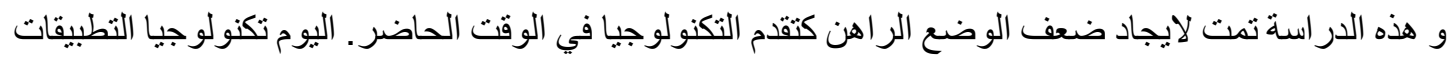

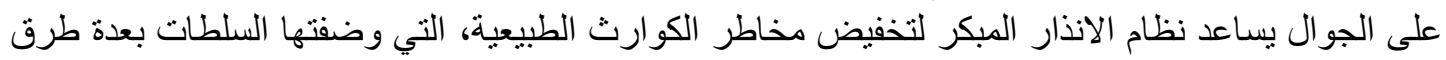
للحد من مخاطر الكوارث الطبيعية. 